\title{
Komunikasi Interpersonal Guru dan Minat Belajar Siswa
}

\author{
Jamil Abdul Aziz \\ Fakultas Tarbiyah Institut PTIQ, Jakarta, Indonesia \\ jamilabdulaziz@ptiq.ac.id
}

\begin{abstract}
Abstrak:
Tujuan dari pendidikan tidak akan terwujud tanpa adanya pendidik yang terampil dalam menjalankan proses pendidikan yang berlangsung. Salah satu keterampilan guru yang penting dimiliki adalah keterampilan berkomunikasi. Hal itulah yang menjadikan alasan peneliti untuk mengambil masalah tentang komunikasi interpersonal guru dan siswa dengan minat belajar siswa di MTs Muhammadiyah 1 Ciputat. Dalam penelitian ini, peneliti menggunakan metode analisis korelasional, dengan pendekatan kuantitatif. Alat pengumpul datanya antara lain : wawancara, observasi, dokumentasi dan angket. Teknik penyebaran angket ini menggunakan teknik random sampling. Adapun dalam pengolahan datanya setelah data dari angket diperoleh, peneliti menggunakan rumus ' $r$ ' product moment. Hasil penelitian menunjukkan ada pengaruh atau korelasi yang positif antara komunikasi interpersonal guru dan siswa (Variabel X) dengan minat belajar siswa (Variabel Y) pada mata pelajaran Sejarah Kebudayaan Islam.
\end{abstract}

Kata Kunci: Pendidikan, Komunikasi Interpersonal, Guru

\begin{abstract}
:
The purpose of education will not be realized without the presence of educators who are skilled in carrying out the ongoing education process. One of the important teacher skills is communication skills. That is what makes the reason for researchers to take the issue of interpersonal communication of teachers and students with student interest in learning at MTs Muhammadiyah 1 Ciputat. In this study, researchers used a correlational analysis method, with a quantitative approach. Data collection tools include: interviews, observation, documentation and questionnaires. This questionnaire distribution technique uses random sampling techniques. As for processing the data after the data from the questionnaire was obtained, researchers used the formula ' $r$ ' product moment. The results showed there was a positive
\end{abstract}


influence or correlation between teacher and student interpersonal communication (Variable $\mathrm{X}$ ) with student learning interest (Variable Y) in the subjects of Islamic Cultural History.

Keywords: Education, Interpersonal Communication, Teacher

\section{Pendahuluan}

Kehidupan yang dilalui oleh manusia pada hakikatnya tidak akan pernah lepas dari unsur pendidikan. Karena dalam kehidupan selalu ada proses interaksi dengan lingkungan. Pendidikan menjadi hal yang sangat penting karena di dalamnya mengatur tentang bagaimana agar manusia bisa menyesuaikan dan menempatkan dirinya dengan sebaik-baiknya dalam proses interaksi tersebut. ${ }^{1}$

Oleh karena itu pendidikan sifatnya menjadi sangat mutlak dalam kehidupan seseorang baik dalam lingkungan keluarga, bangsa, dan negara. Bahkan maju mundurnya suatu bangsa ditentukan oleh kemajuan pendidikan itu sendiri. Hal tersebut karena pendidikan merupakan proses melestarikan, mengalihkan, serta mentransformasikan nilai-nilai kebudayaan dalam segala aspek dan jenisnya kepada generasi selanjutnya. ${ }^{2}$ Adapun makna dari pendidikan itu sendiri secara sederhananya bisa diterjemahkan sebagai proses yang dilalui oleh manusia sehingga pada akhirnya bisa melahirkan kesadaran yang utuh terhadap tindakan, keputusan dan sikap dalam hidupnya. ${ }^{3}$

Akan tetapi, kegiatan belajar mengajar tidak akan terwujud tanpa adanya komunikasi yang baik antara pendidik dan peserta didik, sehingga minat belajar pada siswa untuk mengikuti proses pembelajaran pun cenderung lemah. Padahal sebagaimana yang telah dijelaskan pada pembuka tulisan di bab ini, bahwa pendidikan ada agar kita bisa berinteraksi dengan lingkungan dan manusia dengan baik, dan tentunya dalam proses interaksi yang baik diperlukan komunikasi yang baik. Karena ditinjau dari prosesnya, pendidikan adalah komunikasi antara dua komponen yang terdiri atas manusia, yakni pendidik sebagai komunikator dan peserta didik sebagai komunikan. ${ }^{4}$

Oleh karena itu komunikasi antara guru sebagai pendidik dan siswa sebagai peserta didik perlu dilakukan dengan sebaik mungkin baik itu di dalam kelas maupun di luar kelas, dengan begitu siswa akan merasa diperhatikan oleh gurunya sehingga harapannya adalah

\footnotetext{
${ }^{1}$ Ramayulis, Ilmu Pendidikan Islam, (Jakarta: Kalam Mulia, 2008), hal.17

2 M. Arifin, Ilmu Pendidikan Islam, Tinjauan Teoritis dan Praktis Berdasarkan Pendekatan interdisipliner, (Jakarta: PT. Bumi Aksara, 2009), Hal.8

${ }^{3}$ Sajjad Husein, Krisis Pendidikan Islam, (Bandung: Risalah, 2005), hal.1

${ }^{4}$ Onong Uchjana Effendi, Ilmu Komunikasi: Teori dan Praktek, (Bandung: PT. Remaja Rosdakarya, 2013), hal. 101 
minat untuk belajar dan mengikuti proses pembelajaran akan semakin meningkat hingga akhirnya tercapai suatu pembelajaran yang efektif.

Dalam kegiatan belajar, minat mempunyai peranan yang sangat penting. Karena bila seorang siswa tidak memiliki minat dan perhatian yang besar terhadap objek yang dipelajari maka sulit diharapkan siswa tersebut akan tekun dan memperoleh hasil yang baik dari belajarnya. Sebaliknya, apabila siswa tersebut belajar dengan minat dan perhatian yang besar terhadap objek yang dipelajari, maka hasil yang diperoleh lebih baik. ${ }^{5}$

Akan tetapi yang menjadi kendalanya adalah, tidak semua guru memahami pentingnya membangun komunikasi interpersonal antara guru dan siswa untuk mengetahui bagaimana caranya menumbuhkan dan meningkatkan minat siswa dalam belajar. Sehingga cukup sering kita temui guru yang tidak memiliki keterampilan komunikasi interpersonal secara baik dan efektif dengan siswa atau murid dalam sebuah lembaga pendidikan. Guru cenderung cukup memberikan materi dan tugas-tugas kepada siswa. Tanpa guru itu meneliti dahulu apakah murid-murid tersebut sudah punya minat belajar terhadap mata pelajaran yang ia berikan atau tidak.

Padahal tidak akan ada proses pembelajaran yang baik tanpa adanya komunikasi yang baik antara seorang guru dengan siswanya. Padahal jika dilihat dari fungsinya, seorang guru adalah juga seorang pemimpin. Karena guru adalah orang yang memimpin jalannya proses pembelajaran terutama di dalam kelas. Dan hakikat seorang pemimpin haruslah memiliki kemampuan komunikasi secara baik, secara teori ataupun praktek. Karena sebagian besar waktu yang dihabiskan oleh seorang pimpinan sekitar kisaran $70 \%$ adalah untuk berkomunikasi. $^{6}$

Sehubungan dengan hal yang telah saya paparkan di atas, diduga komunikasi mempunyai pengaruh yang penting dalam menumbuhkan dan meningkatkan minat belajar siswa. Latar belakang inilah yang mendorong penulis untuk melakukan penelitian terkait komunikasi interpersonal guru dan siswa terhadap minat belajar siswa pada mata pelajaran Sejarah Kebudayaan Islam (SKI) di Mts Muhammadiyah 1 Ciputat, Tangerang Selatan, Banten.

Adapun alasan penulis dalam pengambilan judul tersebut adalah sebagai berikut: a) Komunikasi adalah hal fundamental dalam proses belajar-mengajar b) Seringkali komunikasi antara guru dan siswa tidak terjalin secara baik dan efektif sehingga menyebabkan gagalnya

\footnotetext{
${ }^{5}$ Usman Effendi dan Juhaya S Praja, Pengantar Psikologi, (Bandung: Angkasa, 1993), hal.122

${ }^{6}$ Sondang P Siagian, Teori dan Praktek Kepemimpinan, (Jakarta: Rineka Cipta, 2010), Cet-6. H.55
} 
pencapaian sebuah tujuan pembelajaran itu sendiri. c) Mengingat kurannya minat belajar siswa pada mata pelajaran Sejarah Kebudayaan Islam (SKI) di Mts. Muhammadiyah 1 Ciputat.

Dalam penelitian ini, peneliti menggunakan metode analisis korelasional, dengan pendekatan kuantitatif. Alat pengumpul datanya antara lain : wawancara, observasi, dokumentasi dan angket. Penulis mengkorelasikan hasil angket tentang komunikasi interpersonal guru dan siswa (Variabel X) dengan minat belajar siswa (Variabel Y). Populasi yang diteliti adalah seluruh siswa kelas VIII di Mts Muhammadiyah 1 Ciputat yang berjumlah 100 siswa. Sehingga penulis mengambil sampel sebanyak $24 \%$ dari jumlah keseluruhan populasi sebanyak 24 siswa. Teknik penyebaran angket ini menggunakan teknik random sampling. Selain itu peneliti juga menggunakan metode penelitian library research, untuk mengkaji buku-buku dan tulisan ilmiah yang berkaitan dengan masalah yang diangkat oleh peneliti pada artikel ini.

Adapun dalam pengolahan datanya setelah data dari angket diperoleh. Peneliti menggunakan rumus ' $r$ ' Product Moment sehingga peneliti mendapatkan hasil dari nilai ' $r$ ' yang diinginkan ialah 0,5560 . Kemudian peneliti meng-interpretasinya dengan rumus df (degrees of freedom) dengan rumus $\mathrm{df}=\mathrm{N}-2=24-2=22$.

\section{PEMBAHASAN}

\section{Definisi dan Fungsi Komunikasi Interpersonal}

Menurut Andi Abdul Muis, komunikasi interpersonal adalah proses penyampaian dan penerimaan pesan antara pengirim pesan (sender) dengan penerima (receiver) baik secara langsung maupun tidak langsung. ${ }^{7}$ Adapun pengertian dari komunikasi interpersonal menurut Armi Muhammad yaitu proses pengiriman dan penerimaan pesan antara dua orang atau di antara sekelompok kecil orang dengan beberapa efek dan timbal balik seketika. Komunikasi interpersonal mempengaruhi komunikasi dan hubungan dengan orang lain. ${ }^{8}$

Menurut Kathleen S. Vrederber sebagaimana dikutip oleh Dedy Mulyana di dalam bukunya Ilmи Komunikasi, dijelaskan tentang pengertian dari komunikasi interpersonal atau komunikasi antar pribadi adalah proses di mana orang menciptakan dan mengelola hubungan mereka dengan orang lain serta melaksanakan tangung jawab secara timbal balik dalam menciptakan makna. ${ }^{9}$

${ }^{7}$ Andi Abdul Muis, Komunikasi Islam, , (Bandung: PT. Remaja Rosda Karya, 2001), Cet-1. hal. 5

${ }^{8}$ Arrni Muhammad, Komunikasi Organisasi, (Jakarta: Bumi Aksara, 1995), h.159

${ }^{9}$ Dedy Mulyana, Ilmu Komunikasi: Suatu Pengantar, (Bandung: PT. Remaja Rosdakarya, 2002), h. 73 152 | IQ (Ilmu Al-qur'an): Jurnal Pendidikan Islam | Volume 2 No. 022019 
Dari pengertian-pengertian yang telah dijelaskan oleh para ahli di atas, bisa ditarik kesimpulan bahwa komunikasi interpersonal adalah jenis komunikasi yang terjadi antara dua orang atau lebih dalam kelompok kecil dan berlangsung seketika yang tujuannya untuk mengelola hubungan. Dan dalam artikel ini, komunikator yang dimaksud adalah guru dan komunikannya adalah siswa. Komunikasi interpersonal menjadi sangat penting karena dalam komunikasi interpersonal terjadi suatu proses dialogis. Dialog adalah bentuk komunikasi antar pribadi yang menunjukkan terjadinya interaksi antara komunikator dan komunikan.

Adapun fungsi dari komunikasi interpersonal bisa dijelaskan sebagai berikut: ${ }^{10}$ a) Mengenal diri sendiri dan orang lain b) Menciptakan dan memelihara hubungan c) Mengubah sikap dan perilaku

\section{Teori dan Konsep Komunikasi Interpersonal Guru}

Salah satu jenis komunikasi yang paling dominan dan sangat berpengaruh serta memiliki frekuensi terjadinya cukup tinggi adalah komunikasi interpersonal atau komunikasi antar pribadi. ${ }^{11}$ Adapun teori-teori yang membentuk komunikasi interpersonal menurut para ahli, adalah sebagai berikut: ${ }^{12}$

a. Teori self disclosure (model pengungkapan diri)

Self-disclosure merupakan proses mengungkapkan informasi pribadi kita pada orang lain ataupun sebaliknya. Teori ini menjelaskan bagaimana kita berbagi informasi tentang diri kita yang bersifat pribadi kepada orang lain. Teori ini mendorong sifat keterbukaan. Pemahaman Komunikasi Antar Pribadi terjadi melalui: Self-disclosure (pengungkapan diri), Feedback (umpan balik), dan Sensitivitas untuk mengenal orang lain.

\section{b. Teori Penetrasi Sosial}

Teori ini menyatakan bahwa kedekatan antarpribadi itu berlangsung secara bertahap (gradual) dan berurutan yang dimulai dari tahap biasa-biasa saja hingga tahap intim sebagai salah satu fungsi dari dampak saat ini maupun dampak masa depannya. Teori ini menyatakan bahwa relasi akan menjadi semakin intim apabila disclosure berlangsung. Artinya, orang-orang yang melakukan interkasi ini mengaplikasikan teori self disclosure. Pada dasarnya, konsep penetrasi sosial menjelaskan bagaimana kedekatan relasi itu berkembang.

\section{c. Teori pengurangan ketidakpastian}

Teori ini diciptakan oleh Charles Berger dan Richard Calabrese pada tahun 1975. Tujuan mereka dalam mengkonstruksikan teori ini adalah untuk menjelaskan bagaimana komunikasi

\footnotetext{
${ }^{10}$ Nurudin, Sistem Komunikasi Indonesia, (Depok: Raja Grafindo Persada, 2003). hal. 32

${ }^{11}$ Suranto Aw, Komunikasi Interpersonal, (Yogyakarta: Graha Ilmu, 2011), hal.3

${ }^{12}$ Suranto Aw, Komunikasi Interpersonal, hal.51
} 
digunakan untuk mengurangi ketidakpastian antara orang asing yang terikat dalam percakapan mereka. Teori ini menjelaskan, interaksi dilakukan manusia berguna untuk mengurangi ketidakpastian atau meningkatkan prediktabilitas perilaku masing-masing dalam interaksi yang akan mereka kembangkan. Artinya, teori ini menjelaskan keingintahuan kita atas ketidaktahuan kita. Menggali pengetahuan berupa memahami itulah yang merupakan perhatian utama kita.

\section{d. Teori Saling Melengkapi}

Theodore Reik, berpendapat bahwa kita jatuh cinta kepada orang yang memiliki karakteristik yang tidak sama dengan kita . Orang tertarik kepada orang lain yang tidak serupa dalam situasi-situasi tertentu, untuk saling melengkapi. Sehinga tidak terjadi dan lahir kebosanan dan lain-lain. Teori ini meramalkan bahwa orang akan tertarik kepada mereka yang tidak serupa dengannya (artinya, tidak dogmatis).

Para pakar komunikasi, sebagaimana yang dikutip oleh Jalaluddin Rahmat, berpendapat bahwa komunikasi mengandung dua aspek, yaitu: 1) Aspek Isi 2) Aspek Kandungan. Di mana yang kedua mengklasifikasikan yang pertama dan karena itu merupakan metakomunikasi (di luar komunikasi). Komunikasi interpersonal memang bukan hanya menyampaikan informasi tetapi yang terpenting adalah mengatur hubungan di antara dua pihak yang berkomunikasi. ${ }^{13}$

Dalam konteks belajar-mengajar seringkali terdapat berbagai kendala. Seperti suasana belajar yang membosankan, tidak adanya minat belajar pada siswa, dan berbagai macam problema lainnya. Sehingga dengan hal itu seorang guru harus benar-benar mampu mencapai tindakan solutif atas berbagai permasalahan yang ada. Dan mustahil permasalahan dapat terpecahkan tanpa adanya komunikasi yang baik, terutama komunikasi interpersonal antara guru dan siswa secara individu dengan individu melalui sosok yang komunikatif. Dalam kamus ilmiah komunikatif diartikan sebagai 'sifat mencintai dan selalu mengandung imbauan'. ${ }^{4}$

Penjelasan lebih spesifiknya untuk teori dan konsep yang bersifat aplikatif dalam komunikasi interpersonal guru-siswa, adalah sebagai berikut: ${ }^{15}$

a. Guru membantu mengembangkan sikap positif pada diri siswa

b. Guru mendorong siswa menumbuhkan kepercayaan pada diri sendiri

c. Guru membentuk mengungkapkan pikiran dan perasaan siswa

d. Guru bersikap terbuka dan luwes terhadap siswa

13 Jalaluddin Rahmat, Islam Aktual, (Bandung: Penerbit Mizan, 1992), cet. ke-4, hal. 63

${ }^{14}$ Risa Agustin, Kamus Ilmiah Popule Lengkapr, (Surabaya: Serba Jaya, 2001), hal. 240

${ }^{15}$ Moh. Uzer Usman, Menjadi Guru Professional, (Bandung: PT Remaja Rosdakarya, 2010). Cet- 24, hal 135 
Komunikasi Interpersonal Guru dan Minat Belajar Siswa

e. Guru memperlihatkan gairah dan kesungguhan dalam mengajar

f. Guru mampu mengelola interaksi perilaku di dalam kelas

Dalam Al-Qur'an, ada juga isyarat tentang komunikasi interpersonal antara seorang guru dan siwa/muridnya. Karena sebagaimana yang kita tahu al-Qur'an adalah kitab suci yang menjadi pedoman atas segala ilmu pengetahuan dan peradaban yang maju, sehingga ilmu dan teori manapun, al-Quran sebenarnya telah berbicara tentang itu baik eksplisit maupun implisit. ${ }^{16}$ Bentuk komunikasi interpersonal antara guru dan siswa dalam al-Quran bisa ditemukan dalam surat Al-Kahfi ayat 60-70:

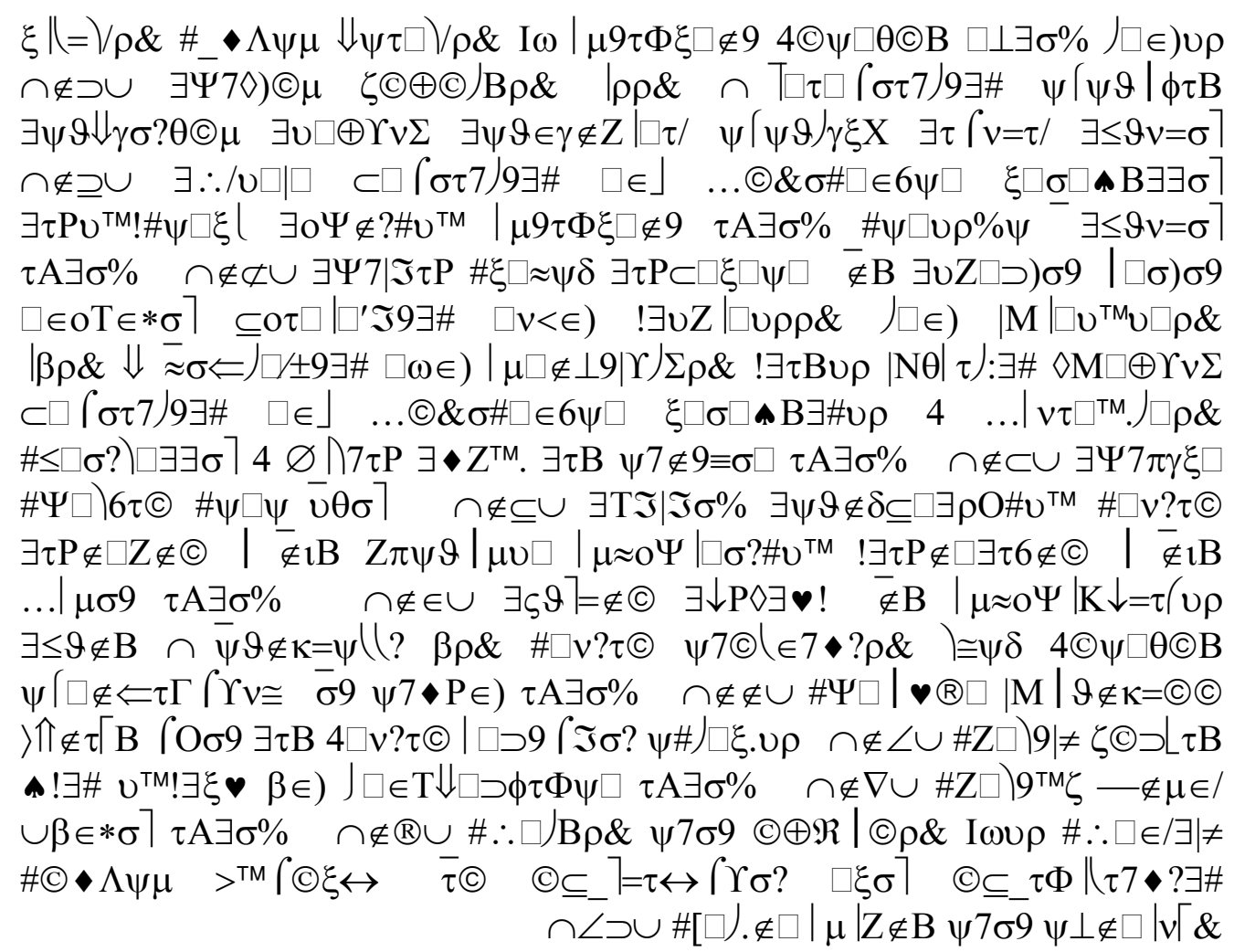

Artinya:

"Dan (ingatlah) ketika Musa berkata kepada muridnya: "Aku tidak akan berhenti (berjalan) sebelum sampai ke pertemuan dua buah lautan; atau aku akan berjalan sampai bertahun-tahun". Maka tatkala mereka sampai ke pertemuan dua buah laut itu, mereka lalai akan ikannya, lalu ikan itu melompat mengambil jalannya ke laut itu. Maka tatkala mereka berjalan lebih jauh, berkatalah Musa kepada muridnya: "Bawalah kemari makanan kita; Sesungguhnya kita telah merasa letih karena perjalanan kita ini." Muridnya menjawab: "Tahukah kamu tatkala kita mecari tempat berlindung di batu tadi, Maka Sesungguhnya aku lupa (menceritakan tentang) ikan itu dan tidak adalah yang melupakan aku untuk menceritakannya kecuali syaitan dan ikan itu mengambil jalannya ke laut dengan cara yang aneh sekali". Musa berkata: "Itulah (tempat) yang kita cari". lalu keduanya kembali, mengikuti jejak mereka semula. Lalu mereka bertemu dengan seorang hamba di antara

${ }^{16}$ Imam Muchlas, Al-Qur'an Berbicara, (Surabaya: Pustaka Progressif, 1996), hal.19 
hamba-hamba Kami, yang telah Kami berikan kepadanya rahmat dari sisi Kami, dan yang telah Kami ajarkan kepadanya ilmu dari sisi Kami.” Musa berkata kepada Khidhr: "Bolehkah aku mengikutimu supaya kamu mengajarkan kepadaku ilmu yang benar di antara ilmu-ilmu yang telah diajarkan kepadamu?". Dia menjawab: "Sesungguhnya kamu sekali-kali tidak akan sanggup sabar bersama aku. Dan bagaimana kamu dapat sabar atas sesuatu, yang kamu belum mempunyai pengetahuan yang cukup tentang hal itu?" Musa berkata: "Insya Allah kamu akan mendapati aku sebagai orang yang sabar, dan aku tidak akan menentangmu dalam sesuatu urusanpun". Dia berkata: "Jika kamu mengikutiku, Maka janganlah kamu menanyakan kepadaku tentang sesuatu apapun, sampai aku sendiri menerangkannya kepadamu". (Q.S Al-Kahfi. 60-70)

Demikianlah dua dialog atau komunikasi yang diungkapkan dalam Al-Qur'an secara interpersonal antara guru dan siswa atau murid. Pertama, antara Nabi Musa dengan muridnya yang bertugas sebagai pembantunya yang menurut beberapa mufassir muridnya itu bernama Yusya bin Nun. Nabi Musa memperlakukan muridnya dengan menunjukkan cinta dan kasih sayang, hal itu bisa dilihat dari cara Nabi Musa memanggil muridnya yaitu li fatahu yang artinya kepada seorang pemuda yang mendampingi, yaitu tiada lain murid yang sekaligus menjadi pembantunya. Begitulah sebaiknya seorang guru, tidak memanggil dan memerintah murid atau siswanya dengan sesuka hati apalagi memanggil dengan panggilan-panggilan yang tidak menyenangkan, sekalipun kedudukan guru lebih tinggi dari murid. ${ }^{17}$

Kemudian yang kedua, adalah dialog antara Nabi Musa dengan Nabi Khidir. Pada posisi ini Nabi Musa ber-status sebagai murid dan Nabi Khidir menjadi gurunya. Gaya komunikasi interpersonal antara Nabi Khidir dan Nabi Musa sangatlah santun dan baik. Nabi Khidir sebagai guru yang lebih pandai dan dalam ilmunya dibandingkan dengan Nabi Musa, tetap menghormati Nabi Musa ketika Nabi Musa memohon kepada Nabi Khidir untuk menjadikannya sebagai murid. ${ }^{18}$

Hal itu dapat kita lihat dari daya ungkap yang dipakai oleh Nabi Khidir pada ayat yang ke 68 dalam surat al-kahfi. Nabi Khidir tidak mengatakan bahwa Nabi Musa itu bodoh dan tak pantas belajar. Akan tetapi Nabi Khidir mengungkapkannya dengan kalimat sesungguhnya engkau tidak akan mampu bersabar bersamaku. Nabi Khidir kemudian mengatakan pada ayat selanjutnya, yaitu bagaimana engkau bisa bersabar sedangkan engkau belum mempunyai pengetahuan yang cukup tentang hal itu?. Dalam ayat itu secara tidak langsung Nabi Khidir sudah memberikan pendidikan kepada Nabi Musa bahwa kesabaran bisa kita peroleh jika kita

17 Muchlis, Hanafi, et. al, Komunikasi dan Informasi; Tafsir Al-Qur'an Tematik , (Jakarta: Lajnah Pentashih Mushaf Al-Qur'an, 2011), hal.324.

${ }^{18}$ Muchlis, Hanafi, et. al, Komunikasi dan Informasi; Tafsir Al-Qur'an Tematik, ....hal. 325 156 | IQ (Ilmu Al-qur'an): Jurnal Pendidikan Islam | Volume 2 No. 022019 
memiliki pengetahuan di dalamnya, sehingga secara tidak langsung membuat Nabi Musa menjadi lebih penasaran dan berminat untuk belajar kepada Nabi Khidir. Hal itu dapat kita lihat dari ungkapan Nabi Musa yang setelah Nabi Khidir berkata seperti itu, Nabi Musa menyanggupi akan mampu bersabar dalam menjalani proses pembelajaran bersama Nabi Khidir.

Walaupun pada akhirnya Nabi Musa tidak bisa bersabar melihat perilaku Nabi Khidir yang terlihat menyimpang menurut agama dalam kacamatanya Nabi Musa, karena terlihat berlawanan menurut akal sehat, seperti membocorkan perahu orang lain dan membunuh anak yang sedang bermain. Sehingga pada akhirnya Nabi Khidir pun menjelaskan bahwa Nabi Khidir melakukan semua itu atas perintah Allah bukan atas kemauan sendiri. Segala yang Nabi Khidir lakukan ada alasan-alasan logis yang tidak diketahui oleh Nabi Musa. Seperti membocorkan perahu yang sebenarnya adalah agar perahu itu tidak dirampas oleh raja zalim yang suka merampas barang rakyatnya, atau membunuh anak kecil yang karena anak itu jika dibiarkan besar akan lebih banyak mudharatnya. ${ }^{19}$

Komunikasi interpersonal yang dilakukan oleh Nabi Musa dan muridnya atau Nabi Musa dan Nabi Khidir sebagai gurunya, sesuai dengan teori-teori yang diungkapkan oleh barat pada awal-awal paragraph pada sub-bab ini. Seperti teori self-disclosure, terlihat dari Nabi Musa yang mengungkapkan dirinya secara terbuka untuk belajar kepada Nabi Khidir juga Nabi Khidir yang terbuka atas segala konsekuensinya kepada Nabi Musa jika ingin belajar bersamanya.

Kemudian teori saling melengkapi yang dicetuskan oleh Theodore, bahwa seserang akan tertarik pada orang yang berbeda. Hal itu terlihat dari Nabi Musa yang semakin tertarik dan bertanya-tanya karena yang dilakukan oleh Nabi Khidir sangat berbeda dengan akal sehat dan jiwanya Nabi Musa. Atau teori pengurangan ketidak pastian yang dicetuskan oleh Charles Barger pada tahun 1975 telah juga diungkap oleh Al-Qur'an dapat dilihat dari sikap Nabi Khidir yang pada akhirnya menjawab semua pertanyaan-pertanyaan Nabi Musa untuk mengurangi ketidak pastian atas setiap tindakannya yang selalu dipertanyakan oleh Nabi Musa.

\section{Minat Belajar Siswa}

\section{Definisi dan Fungsi Minat}

Menurut Poerwadarminta dalam Kamus Umum Bahasa Indonesia, mengatakan bahwa: "Minat merupakan perhatian atau lebih jelasnya lagi, minat adalah kesukaan (kecenderungan hati) pada sesuatu"20 Menurut Mahfudh Salahudin, minat adalah "Perhatian yang mengandung

\footnotetext{
${ }^{19}$ Muchlis, Hanafi, et. al, Komunikasi dan Informasi; Tafsir Al-Qur'an Tematik, .....hal.326

${ }^{20}$ W.J.S Poerwadarminta, Kamus Umum Bahasa Indonesia, (Jakarta: Balai Pustaka, 1987) hal. 650
} 
unsur-unsur perasaan". ${ }^{21}$ Adapun pendapat Bimo Walgito, sebagaimana yang dikutip oleh Ramayulis menyatakan bahwa minat yaitu, "Suatu keadaan dimana seseorang mempunyai perhatian terhadap sesuatu dan disertai dengan keinginan untuk mengetahui dan mempelajari maupun membutuhkan lebih lanjut".22

Dari beberapa pengertian tersebut di atas, disini penulis dapat menyimpulkan bahwa minat adalah merupakan perasaan senang dan tertarik pada suatu obyek, dan kesenangan itu lalu cenderung untuk memperhatikan dan akhirnya aktif berkecimpung dalam obyek tersebut. Seseorang yang berminat terhadap suatu aktifitas akan memperhatikannya secara konsisten dengan rasa senang.

Minat pada dasarnya menjadi sangat penting, terutama dalam proses pendidikan, karena minat punya fungsi seperti:

a. Minat mempengaruhi intensitas cita-cita, sebagai contoh anak yang berminat pada bidang agama maka ia akan bercita-cita menjadi seorang agamawan, ustadz atau seorang tokoh ulama.

b. Minat sebagai pendorong yang kuat. Minat untuk menguasai pelajaran akan mendorong anak untuk senantiasa belajar.

c. Prestasi selalu dipengaruhi oleh jenis dan intensitas minat siswa. Meskipun belajar pada guru yang sama tapi minat siswanya berbeda maka akan menghasilkan hasil yang berbeda.

d. Minat yang terbentuk sejak anak-anak akan sering terbawa seumur hidup, karena minat membawa kepuasan. ${ }^{23}$

\section{Faktor-Faktor Yang Mempengaruhi Minat Belajar Siswa}

Sebagaimana yang telah penulis uraikan sebelumnya mengenai minat belajar siswa bahwa minat belajar merupakan sesuatu yang sangat penting. Karena faktor pendorong keberhasilan siswa adalah adanya minat belajar yang tinggi pada siswa. Adapun faktor-faktor yang mempengaruhi minat belajar siswa, beberapa hal diantaranya, adalah:

Minat seseorang akan semakin tinggi, bila disertai dengan motivasi, baik internal maupun eksternal. Menurut D.P. Tampubolon, minat merupakan "perpaduan antara keinginan dan kemampuan yang dapat berkembang jika ada motivasi", ${ }^{24}$

b. Sikap Guru

\footnotetext{
${ }^{21}$ Mahfudh Salahudin, Pengantar Psikologi Pendidikan, (Surabaya : Bina Ilmu, 1990), h. 45

22 Ramayulis, Metodologi Pengajaran Agama Islam, (Jakarta : Kalam Mulia, 2001), h. 91

${ }^{23}$ Chabib Toha, A Mu'ti, Proses Belajar Mengajar PAI di Sekolah, (Ypgyakarta: Pustaka Pelajar, 1998), h. $107-108$

${ }^{24}$ D.P Tampubolon, Mengembangkan Minat Membaca Pada Anak, (Bandung: Angkasa, 1993), hal.41 158 | IQ (Ilmu Al-qur'an): Jurnal Pendidikan Islam | Volume 2 No. 022019
} 
Salah satu faktor penting yang dapat membangkitkan minat belajar siswa adalah Guru itu sendiri. Menurut Kurt Singer, bahwa "Guru yang berhasil membina kesediaan belajar murid-muridnya, berarti telah melakukan hal-hal yang terpenting yang dapat dilakukan demi kepentingan murid-muridnya". ${ }^{25}$ Komunikasi adalah salah satu komponen yang termasuk ke dalam sikap guru. Bagaimana guru bersikap secara komunikatif terhadap siswa-siswanya.

c. Kesan

Memberikan kesan yang sangat baik dan menyenangkan bagi siswa ketika mengajar merupakan sesuatu yang sangat penting. Karena jika kesan atau pengalaman pertama belajar sudah menyenangkan maka akan timbul minat yang lebih kuat. ${ }^{26}$

d. Keluarga

Keluarga sangatlah berpengaruh bagi perkembangan jiwa anak. Dalam proses perkembangan minat diperlukan dukungan dan perhatian penuh dari keluarga, khususnya orang tua. Oleh karenanya orang tua sangat berpengaruh dalam menentukan minat seorang siswa terhadap mata pelajaran.

e. Teman Pergaulan

Bagi kalangan remaja, pengaruh teman dan pergaulan sangatlah besar karena dalam pergaulan itulah mereka memupuk kepribadiannya dan melakukan aktifitas bersama-sama untuk mengurangi ketegangan dan kegoncangan yang mereka alami. Melalui pergaulan inilah seseorang akan terpengaruh minatnya. Seperti yang dikemukakan oleh L. Crow \& A. Crow, bahwa "minat diperoleh dari pengalaman mereka dari lingkungan di mana mereka tinggal". ${ }^{27}$

f. Lingkungan

Lingkungan tentulah sangat berperan dalam proses pertumbuhan serta menjadi faktor perkembangan anak. Lingkungan adalah keluarga yang mengasuh dan membesarkan anak, besar kecilnya pengaruh lingkungan terhadap proses pertumbuhan dan perkembangan bergantung kepada keadaan lingkungan anak itu sendiri, serta jasmani dan rohaninya.

g. Hobi

Bagi sebagian orang, hobi merupakan salah satu yang bisa menimbulkan lahirnya minat. Sebagai contoh, orang yang hobi menggambar akan timbil minat untuk mempelajari seni lukis. Maka secara tidak langsung faktor hobi akan sangat berengaruh terhadap minat seseorang. ${ }^{28}$

\footnotetext{
${ }^{25}$ Kurt Singer, Membina Hasrat Belajar di Sekolah, (Terj. Berman Sitorus), (Bandung: Remaja Rosda Karya, 1987), hal.83

${ }^{26}$ Ngalim Purwanto, Psikologi Pendidikan, (Bandung: CV Remaja Karya, 1985), hal.64

${ }^{27}$ L. Crow dan A. Crow, Psikologi Pendidikan, (Terj. Kasijan), (Surabaya: Bina Ilmu, 1998), hal. 352

${ }^{28}$ M. Dalyono, Psikologi Pendidikan, (Jakarta: Rineka Cipta, 1997), hal. 130
} 
Siswa yang berminat terhadap suatu pelajaran akan mempelajari dengan sungguhsungguh, karena ada daya tarik baginya. Proses belajar akan berjalan lancar bila disertai minat. Oleh karena itu, guru perlu membangkitkan minat siswa agar pelajaran yang diberikan mudah dipahami.

\section{Strategi Untuk Meningkatkan Minat Belajar Siswa}

Ada beberapa cara yang dapat guru lakukan sebagai cara atau strategi untuk membangkitkan minat belajar siswa, diantaranya sebagai berikut: ${ }^{29}$

a. Membangkitkan adanya suatu kebutuhan

b. Menghubungkan dengan persoalan pengalaman masa lampau

c. Memberikan kesempatan untuk mendapat hasil yang baik

d. Menggunakan berbagai macam bentuk mengajar

Untuk itu guru harus bisa memanfaatkan minat belajar siswa dengan menyediakan kondisi yang mendukungnya. Minat siswa untuk belajar merupakan kekuatan yang bersumber dari diri siswa. Minat ini memang berhubungan dengan kebutuhan siswa untuk mengetahui sesuatu dari objek yang dipelajarinya. Maka dari situlah guru memegang peranan penting sebagai penentu dan pencipta kondisi pembelajaran yaitu dengan cara guru harus lebih interaktif lagi dengan siswa-siswanya. ${ }^{30}$ Selain itu bisa juga seorang guru melakukan hal-hal berikut ini:

a. Mengajar dengan cara yang menarik sesuai dengan tingkat perkembangan anak

b. Menggunakan selingan sehat

c. Mengurangi sejauh mungkin yang dapat mengganggu konsentrasi

d. Memberikan pengertian tentang manfaat pelajaran yang sedang diajarkan

e. Berusaha menghubungkan antara pengalaman siswa dengan apa yang telah diajarkan

f. Menerapkan hukuman dan hadiah yang bijaksana. ${ }^{31}$

Guru harus terampil dan memiliki pengetahuan yang cukup tentang belajar mengajar, karena sebagaimana yang telah dijelaskan oleh Abdur Rokhim Hasan dalam Jurnal Pendidikan Islam IQ, menyatakan bahwa seorang guru memiliki peran yang strategis. Melalui guru, transformasi nilai, ilmu pengetahuan, dan lain-lainnya berlangsung. ${ }^{32}$

${ }^{29}$ Syaiful Bahri, Prestasi Belajar \& Kompetensi Guru, (Surabaya : PT Usaha Nasional, 1994), hal. 48

${ }^{30}$ Syaiful Bahri, Prestasi Belajar \& Kompetensi Guru, .................................. hal. 48 hal.17-18

31 Imansyah Ali Pande, Didaktik Metodik Pendidikan Umum, (Surabaya: Usaha Nasional, 1984),

${ }^{32}$ Abdur Rokhim Hasan, Etos Kerja Guru Menurut Al-Qur'an, Jurnal Pendidikan Islam IQ Vol I, (Jakarta: Fakultas Tarbiyah, Institut PTIQ, 2013), hal.1

160 | IQ (Ilmu Al-qur'an): Jurnal Pendidikan Islam | Volume 2 No. 022019 
Dengan demikian seorang guru haruslah terampil dan memiliki strategi yang banyak dalam menumbuhkan minat belajar siswanya. Agar suatu proses belajar mengajar bisa berjalan dengan lebih baik, dan tujuan pendidikan itu sendiri bisa tercapai.

\section{Hasil Penelitian}

Hasil Analisa Data dan Angket

Hasil Skor Angket dan Hasil Hitung

Variabel X dan Variabel Y

\begin{tabular}{|c|c|c|c|c|c|}
\hline $\begin{array}{l}\text { Nama } \\
\text { Siswa }\end{array}$ & $\mathrm{X}$ & $\mathrm{Y}$ & XY & $\mathrm{X}^{2}$ & $\mathrm{Y}^{2}$ \\
\hline A & 23 & 32 & 736 & 529 & 1024 \\
\hline B & 14 & 30 & 420 & 196 & 900 \\
\hline $\mathrm{C}$ & 31 & 29 & 899 & 961 & 841 \\
\hline $\mathrm{D}$ & 20 & 27 & 540 & 400 & 729 \\
\hline $\mathrm{E}$ & 32 & 30 & 960 & 1024 & 900 \\
\hline $\mathrm{F}$ & 28 & 28 & 784 & 784 & 784 \\
\hline $\mathrm{G}$ & 29 & 29 & 841 & 841 & 841 \\
\hline $\mathrm{H}$ & 22 & 31 & 682 & 484 & 961 \\
\hline I & 31 & 28 & 868 & 961 & 784 \\
\hline $\mathrm{J}$ & 23 & 28 & 644 & 529 & 784 \\
\hline $\mathrm{K}$ & 27 & 32 & 864 & 729 & 1024 \\
\hline $\mathrm{L}$ & 32 & 29 & 928 & 1024 & 841 \\
\hline $\mathrm{M}$ & 33 & 27 & 891 & 1089 & 729 \\
\hline $\mathrm{N}$ & 32 & 34 & 1088 & 1024 & 1156 \\
\hline $\mathrm{O}$ & 34 & 35 & 1190 & 1156 & 1125 \\
\hline $\mathrm{P}$ & 35 & 31 & 1085 & 1225 & 961 \\
\hline $\mathrm{Q}$ & 28 & 36 & 1008 & 784 & 1296 \\
\hline $\mathrm{R}$ & 31 & 30 & 930 & 961 & 900 \\
\hline $\mathrm{S}$ & 31 & 34 & 1054 & 961 & 1156 \\
\hline $\mathrm{T}$ & 24 & 29 & 696 & 576 & 841 \\
\hline $\mathrm{U}$ & 35 & 32 & 1120 & 1225 & 1024 \\
\hline V & 35 & 21 & 651 & 961 & 441 \\
\hline $\mathrm{W}$ & 35 & 34 & 1190 & 1225 & 1156 \\
\hline$X$ & 32 & 32 & 1024 & 1024 & 1024 \\
\hline
\end{tabular}


Jamil Abdul Aziz

\begin{tabular}{|c|c|c|c|c|c|}
\hline $\mathrm{N}=24$ & $\mathrm{X}=693$ & $\mathrm{Y}=728$ & $\mathrm{XY}=$ & $\mathrm{X}^{2}=$ & $\mathrm{Y}^{2}=$ \\
& & & 21193 & 20673 & 22222 \\
\hline
\end{tabular}

Kemudian setelah selesai penghitungan antara dua variabel, langkah selanjutnya adalah mencari $r_{x y}$, dengan rumus:

$$
\begin{gathered}
r_{x y}=\frac{N \sum X Y-\left(\sum X\right)\left(\sum Y\right)}{\sqrt{\left[N \cdot \sum X^{2}-\left(\sum X\right)^{2}\right]\left[N \sum Y^{2}-\left(\sum Y\right)^{2}\right]}} \\
r_{x y}=\frac{24.21193-693.728}{\sqrt{\left[24.20673-693^{2}\right]\left[24.22222-728^{2}\right]}} \\
r_{x y}=\frac{508632-504504}{\sqrt{1596152-480249][533328-529984]}} \\
r_{x y 3434}
\end{gathered}
$$

$r_{x y}=\frac{4128}{\sqrt{53179632}}$

$r_{x y}=\frac{4128}{7292}=0,5660$

Kemudian setelah selesai penghitungan hasil penelitian akhir. Maka langkah selanjutnya yaitu memberikan interpretasi hubungan variabel $\mathrm{x}$ dan variabel $\mathrm{y}$ :

1. Interpretasi secara sederhana (kasar) dari perhitungan di atas hasilnya adalah angka variabel x dan variabel y tidak bertanda negatif. Berarti antara kedua variabel tersebut terdapat korelasi positif. Dengan memperhatikan besarnya rxy adalah 0. 5660 yang besarnya melampaui kisaran 0,40-0,70. Berarti korelasi variabel $\mathrm{x}$ dan y termasuk pada variabel sedang atau cukup, sebagaimana yang telah dijelaskan oleh tabel indeks korelasi yang telah penulis jelaskan pada BAB III Poin Interpretasi data.

2. Interpretasi dengan menggunakan tabel nilai, memakai rumus:

' $\mathrm{r}$ ' $: \mathrm{df}=\mathrm{N}-\mathrm{nr}$

' $\mathrm{r}$ ' $: \mathrm{df}=24-2$

' $\mathrm{r}$ ' $=22$ 
Dengan memeriksa tabel nilai koefesien korelasi ' $r$ ' Product Moment no urut $22^{33}$, nilai ' $r$ ' $=$ Pada taraf siginifikansi, $1 \%=0,404$ maupun pada taraf $5 \%=0,515$. Karena nilai ro atau rxy lebih besar dari rt/ nilai tabel 0, $5660>0,404$ atau pada taraf signifikansi 5\% nilai rxy atau ro $0,5660>0,515$

Dari penjelasan dan interpretasi di atas maka peneliti dapat mengambil kesimpulan bahwa hipotesis alternatif yang peneliti ajukan dapat diterima. Ini berarti bahwa terdapat pengaruh atau hubungan yang signifikan antara Komunikasi Interpersonal Guru dan Siswa Terhadap Minat Belajar Siswa Pada Mata Pelajaran Sejarah Kebudayaan Islam.

\section{KESIMPULAN}

Berdasarkan pada hasil penelitian dan analisa yang telah penulis uraikan pada bab-bab sebelumnya mengenai pengaruh komunikasi interpersonal guru dan siswa terhadap minat belajar siswa, maka penulis dapat memberi kesimpulan sebagai berikut: Ada pengaruh atau korelasi positif yang signifikan antara komunikasi interpersonal guru dan siswa dengan minat belajar siswa pada mata pelajaran Sejarah Kebudayaan Islam di Mts Muhammadiyah 1 Ciputat, sebagaimana yang telah dipaparkan pada bab iv mengenai hasil peneltian yang telah diperoleh bahwa $r_{0}$ lebih besar hasilnya dari $r_{t}$. Baik pada taraf signifikansi 5\% ataupun $1 \% . r_{0}=0$, $5660>0,515\left(r_{t} \cdot \operatorname{taraf} 5 \%\right) / r_{0}=0,5660>0,404\left(r_{t}\right.$ taraf $\left.1 \%\right)$.

Berdasarkan kesimpulan yang diperoleh dalam penelitian ini, maka penulis menyatakan: setiap guru hendaknya selalu menjalin hubungan dan komunikasi yang baik dengan siwa-siswanya. Bukan hanya sekedar mengajar dan memberikan materi semata sehingga membuat siswa-siswanya tidak berminat atau merasa bosan dalam mengikuti proses pembelajaran yang dilaksanakan. Hendaknya guru lebih kreatif lagi dalam melaksanakan tugasnya dalam mengajar, serta memberikan tanggapan dan solusi yang baik terhadap siswasiswa yang minat belajarnya kurang.

\section{DAFTAR PUSTAKA}

Agustin, Risa, Kamus Ilmiah Popule Lengkapr, (Surabaya: Serba Jaya, 2001)

Arifin, M Ilmu Pendidikan Islam, Tinjauan Teoritis dan Praktis Berdasarkan Pendekatan

${ }^{33}$ Anas Sudjono, Pengantar Statistik Pendidikan, (Jakarta: PT. Raja Grafindo Persada, 2010), cet-22. Hal. 402 
Jamil Abdul Aziz

interdisipliner, (Jakarta: PT. Bumi Aksara, 2009)

Bahri, Syaiful, Prestasi Belajar \& Kompetensi Guru, (Surabaya : PT Usaha Nasional, 1994)

Dalyono, M., Psikologi Pendidikan, (Jakarta: Rineka Cipta, 1997)

Effendi, Usman, S Praja, Juhaya, Pengantar Psikologi, (Bandung: Angkasa, 1993)

Effendi, Onong Uchjana, Ilmu Komunikasi: Teori dan Praktek, (Bandung: PT. Remaja

Rosdakarya, 2013)

Hanafi, Muchlis, et. al, Komunikasi dan Informasi; Tafsir Al-Qur'an Tematik, (Jakarta: Lajnah Pentashih Mushaf Al-Qur'an, 2011)

Hasan, Abdur Rokhim, “Etos Kerja Guru Menurut Al-Qur’an”, Jurnal Pendidikan Islam IQ

Vol I, (Jakarta: Fakultas Tarbiyah, Institut PTIQ, 2013)

Husein, Sajjad, Krisis Pendidikan Islam, (Bandung: Risalah, 2005)

L. Crow dan A. Crow, Psikologi Pendidikan, (Terj. Kasijan), (Surabaya: Bina Ilmu, 1998)

Muchlas, Imam, Al-Qur'an Berbicara, (Surabaya: Pustaka Progressif, 1996)

Muhammad, Arrni, Komunikasi Organisasi, (Jakarta: Bumi Aksara, 1995)

Muis, Andi Abdul, Komunikasi Islam, , (Bandung: PT. Remaja Rosda Karya, 2001)

Mulyana, Dedy, Ilmu Komunikasi: Suatu Pengantar, (Bandung: PT. Remaja Rosdakarya, 2002)

Nurudin, Sistem Komunikasi Indonesia, (Depok: Raja Grafindo Persada, 2003)

Pande, Imansyah Ali, Didaktik Metodik Pendidikan Umum, (Surabaya: Usaha Nasional, 1984)

Poerwadarminta, W.J.S, Kamus Umum Bahasa Indonesia, (Jakarta: Balai Pustaka, 1987)

Purwanto, Ngalim, Psikologi Pendidikan, (Bandung: CV Remaja Karya, 1985)

Rahmat, Jalaluddin, Islam Aktual, (Bandung: Penerbit Mizan, 1992)

Ramayulis, Ilmu Pendidikan Islam, (Jakarta: Kalam Mulia, 2008)

Ramayulis, Metodologi Pengajaran Agama Islam, (Jakarta : Kalam Mulia, 2001)

Salahudin, Mahfudh, Pengantar Psikologi Pendidikan, (Surabaya : Bina Ilmu, 1990)

Siagian, Sondang P, Teori dan Praktek Kepemimpinan, (Jakarta: Rineka Cipta, 2010)

Singer, Kurt, Membina Hasrat Belajar di Sekolah, (Terj. Berman Sitorus), (Bandung: Remaja

Rosda Karya, 1987)

Sudjono, Anas, Pengantar Statistik Pendidikan, (Jakarta: PT. Raja Grafindo Persada, 2010)

Suranto, Komunikasi Interpersonal, (Yogyakarta: Graha Ilmu, 2011)

Tampubolon, D.P, Mengembangkan Minat Membaca Pada Anak, (Bandung: Angkasa, 1993)

Toha, Chabib, A Mu’ti, Proses Belajar Mengajar PAI di Sekolah, (Ypgyakarta: Pustaka 
Komunikasi Interpersonal Guru dan Minat Belajar Siswa

Pelajar, 1998)

Usman, Moh. Uzer, Menjadi Guru Professional, (Bandung: PT Remaja Rosdakarya, 2010) 